\title{
Adverse Effect on Bacteria of Peritoneal Dialysis Solutions that Contain Acetate*
}

\author{
JAMES A. RICHARDSON, $\dagger$ M.D., F.A.C.P. ; KENNETH A. BORCHARDT, $\ddagger$ PH.D.
}

\begin{abstract}
Summary : Peritoneal dialysis solutions which contained $43 \mathrm{mEq}$ per litre of acetate had a greater antibacterial effect than those containing lactate. Bacteria were isolated from 15 separate clinical infections, each caused by Escherichia coli, Pseudomonas sp., or Staphylococcus aureus. Incubation in the dialysate made with acetate substantially reduced the number of viable organisms from all but one of the $\mathbf{4 5}$ isolates. It is suggested that solutions made with acetate may provide greater protection from peritonitis.
\end{abstract}

\section{Introduction}

Three years ago, for reasons of economy, we began to make solutions for peritoneal dialysis in our own pharmacy. Instead of sodium lactate, which serves as the source of base in commercial peritoneal dialysates, we substituted sodium acetate as suggested by Mion, Hegstrom, Boen, and Scribner (1964). At the same time we began to use new tightly fitting peritoneal catheters (Trocath) and a relatively closed system of dispensing the fluids (Richardson, Philbin, and Herron, 1968). Since these changes were made no bacterial peritonitis has occurred in over 300 patients treated with dialysis. Though the mechanical changes in technique may have accounted in part for a low incidence of infection, the complete absence of peritonitis suggested that the substitution of acetate for lactate had helped to eliminate this complication. To test this possibility the effect of incubation in dialysates made with acetate or lactate on numbers of viable pathogenic bacteria was examined.

\section{Methods}

Two kinds of dialysate solution were made by dissolving reagent-grade salts and glucose in distilled water. The solutions differed primarily in their content of sodium acetate or lactate. These salts were added to one or other of the solutions in an amount calculated to produce $43 \mathrm{mEq}$ of the anion per litre, the same concentration of lactate used in commercial dialysate. The $p \mathrm{H}$ of the solutions made with lactate $(5 \cdot 3)$ was adjusted to that of the solutions made with acetate $(6 \cdot 8)$ by substituting about $2 \mathrm{mEq}$ of hydroxide, as sodium hydroxide per litre for a similar quantity of chloride. Two separate batches of each kind of solution were made, each batch being used in about half the tests with the bacteria. The mean values of duplicate measurements of the two batches are shown in Table I. The solutions were sterilized by Seitz filtration and

\begin{tabular}{|c|c|c|c|c|c|c|}
\hline & $\underset{(\mathrm{mEq} / \mathrm{l} .)}{\mathrm{Na}^{+}}$ & $\underset{(\mathrm{mEq} / 1 .)}{\mathrm{Ca}^{++}}$ & $\underset{(\mathrm{mEq} / \mathrm{l} .)}{\mathrm{Mg}^{++}}$ & $\underset{(\mathrm{mEq} / 1 .)}{\mathrm{Cl}^{-}}$ & $\begin{array}{c}\text { Glucose } \\
\text { (mg./100 ml. })\end{array}$ & $p \mathrm{H}$ \\
\hline $\begin{array}{l}\text { With acetate } \\
\text { With lactate }\end{array}$ & $\begin{array}{l}137 \\
137\end{array}$ & $\begin{array}{l}3.9 \\
3.9\end{array}$ & $\begin{array}{l}1 \cdot 5 \\
1 \cdot 5\end{array}$ & $\begin{array}{l}100 \\
98^{*}\end{array}$ & $\begin{array}{l}1,617 \\
1,617\end{array}$ & $\begin{array}{l}6.8 \\
6.8\end{array}$ \\
\hline
\end{tabular}

* About $2 \mathrm{mEq}$ of hydroxide was substituted for chloride to increase the $p \mathrm{H}$ of the solution.

* From the Research Dialysis Center and Department of Pathology, Public Health Service Hospital, San Francisco, California 94118, U.S.A.

This project was supported in part by N.I.H. Grant AM 10642.

$\dagger$ Associate Chief of Medicine; Chief, Renal Service.

$¥$ Chief of Microbiology. refrigerated in sterile glass containers. Their continued sterility was confirmed by periodic cultures for bacteria and fungi during the subsequent tests.

Staphylococcus aureus, Escherichia coli, and Pseudomonas sp.-common causes of peritonitis resulting from dialysiswere chosen for study. Fifteen isolates were obtained from separate clinical infections caused by each of the three pathogens. Bacteria from each isolate were inoculated into $10 \mathrm{ml}$. of brain-heart infusion broth and incubated at $35^{\circ} \mathrm{C}$. for 18 hours. These cultures were then used in two separate procedures. In one, a $0.01-\mathrm{ml}$. aliquot was inoculated into a $5-\mathrm{ml}$. sample of each of the two kinds of dialysate. In the other, dilutions of the broth culture were made with saline and aliquots mixed in pour plates with tryptose agar (Difco). The mean number of bacterial colonies present after incubation of the pour plates was used to calculate the number of viable organisms of that isolate placed into the two tubes of dialysate.

Both the inoculated dialysate and pour plates were incubated for 18 hours at $35^{\circ} \mathrm{C}$. After incubation dilutions in saline of aliquots from each tube of inoculated dialysate were mixed in pour plates with tryptose agar. These were incubated and counted in the same manner to establish the number of viable organisms remaining after incubation in each millilitre of dialysate.

\section{Results}

The results are given in Table II. The number of viable bacteria introduced into each millilitre of solution is shown with the corresponding number of viable organisms which remained after 18 hours of incubation. Half of the isolates of $E$. coli and Pseudomonas sp. had an increase in number of bacilli in the solution with lactate, and the other half had a modest decrease. In the solution that contained acetate the number of these bacilli was decreased in all but one instance. The number of viable staphylococci was consistently diminished in either solution. For all three kinds of bacteria the largest reduction in number of an isolate always occurred in the fluid which contained acetate. Organisms from 11 of the isolates of Staph. aureus and from two of those of $E$. coli were completely eliminated by incubation in an acetate solution, whereas complete killing of bacteria never occurred in a lactate solution.

\section{Discussion}

Baillod, Comty, and Shaldon (1966) stated, without documentation, that peritoneal dialysis solutions made with acetate have a bacteriostatic effect. There is other evidence that this may be so. For many years acetic acid as vinegar, as well as lactic acid, has been used to preserve food. Levine and Fellers (1940) showed that a toxic effect of acetic acid on organisms implicated in food spoilage was not entirely attributable to the level of hydrogen ion concentration, and that acetic acid had a greater antibacterial effect than lactic or hydrochloric acid. Hentges (1967), using shigellae, and Owen (1946), using "the coli-proteus-pyocyaneus group" and Staph. aureus, also demonstrated an antibacterial effect of acetic acid which could 
TABLE I1.-Numbers of Viable Bacteria per ml. of Dialysate

\begin{tabular}{|c|c|c|c|c|c|c|c|c|c|}
\hline \multirow{3}{*}{ Isolate } & \multicolumn{3}{|c|}{ Escherichia coli } & \multicolumn{3}{|c|}{ Pseudomonas species } & \multicolumn{3}{|c|}{ Staphylococcus aureus } \\
\hline & \multirow{2}{*}{$\begin{array}{c}\text { Before } \\
\text { Incubation }\end{array}$} & \multicolumn{2}{|c|}{ After Incubation } & \multirow{2}{*}{$\begin{array}{c}\text { Before } \\
\text { Incubation }\end{array}$} & \multicolumn{2}{|c|}{ After Incubation } & \multirow{2}{*}{$\begin{array}{c}\text { Before } \\
\text { Incubation }\end{array}$} & \multicolumn{2}{|c|}{ After Incubation } \\
\hline & & Acetate & Lactate & & Acetate & Lactate & & Acetate & Lactate \\
\hline $\begin{array}{r}1 \\
2 \\
3 \\
4 \\
5 \\
6 \\
7 \\
8 \\
9 \\
10 \\
11 \\
12 \\
13 \\
14 \\
15\end{array}$ & $\begin{array}{l}5.0 \times 10^{6} \\
8.0 \times 10^{6} \\
5.2 \times 10^{6} \\
1.6 \times 10^{7} \\
1.0 \times 10^{6} \\
1.6 \times 10^{7} \\
1.2 \times 10^{7} \\
6.4 \times 10^{6} \\
1.2 \times 10^{7} \\
4.5 \times 10^{7} \\
9.0 \times 10^{7} \\
6.8 \times 10^{7} \\
4.0 \times 10^{6} \\
2.5 \times 10^{6} \\
7.2 \times 10^{6}\end{array}$ & $\begin{array}{c}6.0 \times 10^{2} \\
1.5 \times 10^{3} \\
3.6 \times 10^{3} \\
1.5 \times 10^{3} \\
6.0 \times 10^{2} \\
1.5 \times 10^{3} \\
<1 \times 10^{1} \\
21 \times 10^{1} \\
<1 \times 10^{1} \\
2.0 \times 10^{2} \\
0 \\
0 \\
1.0 \times 10^{2} \\
1.7 \times 10^{6} \\
8.0 \times 10^{2}\end{array}$ & $\begin{array}{l}2.8 \times 10^{6} \\
3.5 \times 10^{8} \\
1.2 \times 10^{7} \\
3.5 \times 10^{8} \\
2.8 \times 10^{6} \\
3.5 \times 10^{8} \\
6.0 \times 10^{7} \\
1.2 \times 10^{8} \\
1.4 \times 10^{8} \\
4.6 \times 10^{8} \\
1.0 \times 10^{5} \\
1.0 \times 10^{8} \\
4.4 \times 10^{8} \\
1.4 \times 10^{7} \\
2.5 \times 10^{6}\end{array}$ & $\begin{array}{l}1.4 \times 10^{5} \\
1.6 \times 10^{5} \\
2.6 \times 10^{5} \\
4.1 \times 10^{6} \\
3.2 \times 10^{6} \\
1.1 \times 10^{7} \\
6.5 \times 10^{7} \\
5.5 \times 10^{7} \\
4.5 \times 10^{7} \\
3.1 \times 10^{6} \\
4.0 \times 10^{6} \\
1.0 \times 10^{7} \\
1.1 \times 10^{6} \\
3.6 \times 10^{6} \\
3.2 \times 10^{6}\end{array}$ & $\begin{array}{l}<1 \times 10^{4} \\
<1 \times 10^{4} \\
3.4 \times 10^{5} \\
<1 \times 10^{4} \\
<1 \times 10^{4} \\
<1 \times 10^{4} \\
2.0 \times 10^{3} \\
4.0 \times 10^{2} \\
6.0 \times 10^{3} \\
5.5 \times 10^{4} \\
4.8 \times 10^{3} \\
2.0 \times 10^{4} \\
4.0 \times 10^{1} \\
3.3 \times 10^{2} \\
4.0 \times 10^{2}\end{array}$ & $\begin{array}{l}9.3 \times 10^{6} \\
1.3 \times 10^{7} \\
1.4 \times 10^{7} \\
5.2 \times 10^{7} \\
5.0 \times 10^{7} \\
6.0 \times 10^{7} \\
5.5 \times 10^{7} \\
3.4 \times 10^{7} \\
3.4 \times 10^{7} \\
1.4 \times 10^{7} \\
3.0 \times 10^{7} \\
9.0 \times 10^{6} \\
4.1 \times 10^{4} \\
1.0 \times 10^{4} \\
2.5 \times 10^{6}\end{array}$ & $\begin{array}{l}6.0 \times 10^{8} \\
1.0 \times 10^{6} \\
3.0 \times 10^{7} \\
7.0 \times 10^{7} \\
3.0 \times 10^{7} \\
4.5 \times 10^{7} \\
4.9 \times 10^{5} \\
1.4 \times 10^{5} \\
2.4 \times 10^{6} \\
2.3 \times 10^{6} \\
2.4 \times 10^{6} \\
2.1 \times 10^{6} \\
1.3 \times 10^{8} \\
3.1 \times 10^{6} \\
1.5 \times 10^{6}\end{array}$ & $\begin{array}{c}0 \\
0 \\
0 \\
0 \\
0 \\
0 \\
<1 \times 10^{1} \\
0 \\
<1 \times 10^{1} \\
0 \\
0 \\
0 \\
0 \\
0 \\
5.5 \times 10^{2} \\
3.0 \times 10^{1}\end{array}$ & $\begin{array}{l}1.8 \times 10^{2} \\
1.8 \times 10^{2} \\
1.4 \times 10^{3} \\
1.6 \times 10^{3} \\
1.3 \times 10^{3} \\
2.5 \times 10^{4} \\
1.1 \times 10^{4} \\
1.4 \times 10^{4} \\
1.1 \times 10^{5} \\
4.0 \times 10^{1} \\
4.0 \times 10^{1} \\
3.6 \times 10^{4} \\
3.0 \times 10^{4} \\
5.8 \times 10^{4} \\
1.6 \times 10^{2}\end{array}$ \\
\hline
\end{tabular}

not be entirely accounted for by alterations in $\mathrm{pH}$. Dilute solutions of acetic acid have proved useful in the treatment of superficial wounds infected with Pseudomonas aeruginosa (Phillips, Lobo, Fernandes, and Gundara, 1968) and in preventing bacilluria from indwelling Foley catheters (Martin and Bookrajian, 1962).

At first glance a toxic influence of solutions that contain acetate or lactate on bacteria seems paradoxical. The close relation of the two substances to the tricarboxylic acid and glyoxylate cycles would seem to indicate their easy use in bacterial metabolism. Kogut and Podoski (1953), however, reported that cells of Ps. fluorescens grrovn with acetate as their principal source of carbon did not oxidize tricarboxylic acid intermediates as well as cells grown with other sources of carbon. Similarly, Jacobson, Bartholomaus, and Gunsalus (1966) showed that acetate, pyruvate, and lactate suppressed production by $P$ s. putida of malate synthase-an important enzyme of the glyoxylate cycle-and that acetate had the greatest suppressive effect. Their experiments suggest that solutions which contained acetate or lactate could prove toxic to bacteria by affecting the enzymes of critical metabolic pathways. This is supported by recent demonstrations that neutral solutions of acetate can inhibit enzymes frøm animal tissues (Warren, Stowring, and Morales, 1966) and alter the etructure of a model peptide (Robinson and Jencks, 1965).

In our experiment the solutions made with lactate were altered purposely by the addition of small quantities of sodium hydroxide to eliminate the effect of differences in $p H$ on bacterial viability. As a result, differences in the capacities of the solutions to diminish numbers of viable bacteria are more likely to be a consequence of their content of acetate or lactate anion. Acetate had the greater antibacterial effect; dialysate made with acetate reduced the number of viable pathogenic bacteria more frequently and to a greater extent than did similar solutions made with lactate. These results suggest, but do not prove, that substitution of acetate for lactate in peritoneal dialysate may provide protection from peritonitis. Since dialysate made with acetate has proved to be efficacious and safe in a large number of patients undergoing peritoneal dialyses (Mion et al., 1964 ; Richardson et al., 1968), its greater antibacterial effect commends its use.

\section{REFERENCES}

Baillod, R. A., Comty, C., and Shaldon, S. (1966). Proceedings of the 2nd Conference of the European Dialysis and Transplant Association, p. 109. Excerpta Medica Foundation Congress Series, No. 103. Amsterdam.

Hentges, D. J. (1967). Fournal of Bacteriology, 93, 2029.

Jacobson, L. A., Bartholomaus, R. C., and Gunsalus, I. C. (1966). Biochemistry and Biophysics Research Communications, 24, 955.

Kogut, M., and Podoski, E. P. (1953). Biochemical fournal, 55, 800.

Levine, A. S., and Fellers, C. R. (1940). Fournal of Bacteriology, 39, 499.

Martin, C. M., and Bookrajian, E. N. (1962). Archives of Internal Medicine, 110, 703.

Mion, C. M., Hegstrom, R. M., Boen, S. T., and Scribner, B. H. (1964). Transactions. American Society for Artificial Internal Organs, 10, 110.

Owen, C. R. (1946). Fournal of Bacteriology, 52, 353.

Phillips, I., Lobo, A. Z., Fernandes, R., and Gundara, N. S. (1968). Lancet, 1, 11.

Richardson, J. A., Philbin, P. E., and Herron, G. R. (1968). British Medical fournal, 4, 757.

Robinson, D. R., and Jencks, W. P. (1965). fournal of the American Chemical Society, 87, 2470.

Warren, J. C., Stowring, L., and Morales, M. F. (1966). Fournal of Biological Chemistry, 241, 309. 